\title{
Úvahy nad českým rodinným právem ve světle stého výročí tzv. manželské novely
}

\section{Considerations on Czech Family Law in the Light of the Centenary of the so-called Marriage Amendment}

\author{
Zdeňka Králíčková*
}

\begin{abstract}
Abstrakt
Clánek je vénován vývoji manželského práva ve svètle tru. manžllské novely prüjaté pred sto lety. Lzue řici, že tento zákon z.počátku dvacátého stoleti predstavuje významný počin, který české rodinné právo ovlivnil na dloubá léta. Byl nastolen správný smèr svobodné volby civilni či církevni formy uzavréni manželstuí, došlo k omezueni prekáẓ̌ek manželstvi a rozvod manželstvi se významnè zjednodušil. Klade se otázka, jaké jsou potréby současné ceské společnosti? Je na mistě de lege ferenda zakotvit v rámci legislativního „prorodinnébo balickeu" trv. rozvod u notáre?
\end{abstract}

\section{Klíčová slova}

Rodinné právo; manželské právo; uzavíráni manželstvi; prekážky manželstvi; rozvod; tzu. manželská novela; rok 1919; vývoj; nový občanský zákonik; dalši legislativni návrh.
Abstract
The article is devoted to the development of marital law in the light the so-called marriage amendment adopted a bundred years ago. We can say that this law of the early twenties century was an important achievement that influenced Czech family law for many years. The right direction of free choice of civil or church form of marriage was established, the obstacles to marriage were limited and divorce law was significantly simplified. The question is what are the needs of contemporary Czech society? It is appropriate to anchor within the legislative framework of "pro-family package" so-called divorce by a notary?

\section{Keywords}

Family Law; Marital Law; Conclusion of Marraige; Impediments of Marriage; Divorce; so-called Marriage Amendment; the Year of 1919; Development; New Civil Code; Pending Draft.

\section{Úvodem}

O rodinném právu se traduje, že odráží více či méně tvář té které společnosti. Mnozí familiaristé proto dokonce tvrdí, že rodinné právo není možné měnit den ze dne, radikálně, nebot’ reflektuje vývoj rodiny a rodinného života jako takového, kulturu a v neposlední řadě i náboženství, zejména jde-li o koncept manželství a jeho rozlučitelnost

\footnotetext{
* Prof. JUDr. Zdeňka Králíčková, Ph.D., Katedra občanského práva, Právnická fakulta, Masarykova univerzita, Brno / Department of Civil Law, Faculty of Law, Masaryk University, Brno, Czech Republic / E-mail: Zdenka.Kralickova@law.muni.cz / ORCID: 0000-0002-4838-4790
} 
za života manželů. Lze říci, že ani podobu rodiny a rodinného života nelze výrazně ovlivnit zákonem. Tento fakt vystihuje také v českém prostředí poměrně známý výrok ze starší italské doktríny, který lze volně parafrázovat slovy „rodina je skalnatý ostrov, který můře právo svými vlnami pouze omývat"."

Všeobecně se ví, že konz̧ervativni názory obhajující tradice a vyjadřující nechut' až averzi ke změnám rodinného práva, at' už skutečně nutným, či nikoli, vždy zaznívaly a stále rezonují jak na stránkách odborné literatury, tak mezi politiky či laiky, širokou veřejností. V této věci se kladla a stále klade celá řada otázek, které vybízejí k hledání odpovědí, zejména ve vazbě na vývoj právní úpravy rodinných práv v mnoha evropských zemích. ${ }^{2}$ I na starém kontinentu jsou stále země, které si svoje tradice chrání. Nejen, že manželství jako základní statusový poměr rodinného práva je v jejich zákonících nadále pojímáno jako svazek muže a ženy a osobám stejného pohlaví není vyhrazeno ani registrované partnerství jako statusový poměr omezenějšího obsahu, ale do ústav a ústavních listin jsou vtělovány klauzule chránící manželství v jeho tradiční podobě, tj. jako svazek jednoho muže a jedné ženy. ${ }^{3}$

$\mathrm{Na}$ druhou stranu, nelze zavírat oči před novými jevy, které jsou spojeny s rodinou a rodinným životem. V některých právních řádech se projevují naprosto liberální tendence, $\mathrm{v}$ důsledku kterých je manželství pojímáno genderově neutrálně ${ }^{4}$ a rozvod manželství již není patologizován, ale brán jako legitimní řešení krize manželského soužití. ${ }^{5}$ Také koncepce rodičovství je pojata velmi široce. Nejde jen o náhradní mateřství a problémy s ním spojené, ale i o práva domnělých otců a vazby nezletilých dětí na rodinu původu

1 Jde o mnohokrát opakovaný výrok italského familiaristy. Viz JEMOLO, A. C. La Famiglia e il diritto. Ann. Sen. Giur. Università di Catania, 1948, III. Dostupné z: http://spaziofamigliablog.altervista.org/famiglia-e-diritto/?doing_wp_cron=1565352315.0589270591735839843750 [cit. 9. 8. 2019].

Z literatury parafrázující uvedený citát srov. nap̌r. RESCIGNO, P. Interessi e conflitti nella famiglia: l’instituto della „mediazione familiare. Giur. it., 1995, IV, s. 74; a dále GIAIMO, G. La mediazione familiare nei procedimenti di separazione personale e di divorsio. Profili comparatistici. Riv. dir. civ., 2001, č. 4, s. 1606.

2 Viz zejm. DOUGLAS, G. a N. LOWE. The Continuing Evolution of Family Law. Bristol: Jordan Publishing Limited, 2009; McGLYNN, C. Families and European Union. Law, Potilics and Pluralism. Cambridge: Cambridge University Press, 2006; nejnověji viz SCHERPE, J. M. (ed.). European Family Law. Volumes I. - IV. Cheltenham - Northampton: Edward Elgar Publishing, 2016.

3 Viz např. vývoj na Slovensku. K tomu blíže PAVELKOVÁ, B. Marriage (not for all) in the Slovak Republic. In: Dny práva 2018 - Days of Law 2018 [online]. Brno: Masarykova univerzita, 2019. ISBN 978-80-210-9304-1.

4 V podrobnostech ELISCHER, D. Alternativní formy soužití a registrované partnerství v širších souvislostech. In: MELZER, F., P. TÉGL a kol. Občanský zákoník (』 655-793). Velký komentár. Svazek IV/1. Praha: Leges, 2016, s. 817 a násl.; SŐRGJERD, C. Reconstruction Marriage. The Legal Status of Relationships in Changing Society. Cambridge - Antwerp - Portland: Intersentia, 2012.

5 K tomu viz napr. VERSCHRAEGEN, B. Mowing to the Same Destination? Recent Trends in the Law of Divorce. In: ANTOKOLSKAIA, M. (ed.). Convergence and Divergence of Family Law in Europe. AntwerpenOxford: Intersentia, 2007, s. 159 a násl.; Ze starší tuzemské literatury viz např. RADVANOVÁ, S. Analýza současné zákonodárné a soudní rozvodové praxe. Socialistická zákonnost, 1989, č. 3, s. 31 a násl.; Nejnověji viz KORNEL, M. a L. ZATLOUKALOVÁ. Quo Vadis Marriage?. In: Dny práva 2018 - Days of Law 2018 [online]. Brno: Masarykova univerzita, 2019. ISBN 978-80-210-9304-1. 
v prrípadě osvojení apod. I u nás se hovoří - mnohdy ve vazbě na judikaturu Ústavního soudu - kupř. o „deklaraci pokrevního pouta“6 a o „,rodičovstvi““ dvou mužů, ${ }^{7}$ byt' je právní úprava rodinného práva v novém občanském zákoníku tradiční, resp. poměrně konzervativní. ${ }^{8}$ Ostatně, i z Principu a východisek nového kodexu sonkromébo práva se podává záměr hlavních zpracovatelů ponechat tuto oblast práva bez významných změn. ${ }^{10} \mathrm{~V}$ souvislosti s novými „jevy“ bývá často namítáno, že se jedná o „jevy okrajové“, kterými se familiaristika zaobírá nepřiměřeně, mnohdy na úkor „skutečných“ problémů, které by si zasloužily hlubšího zkoumání a větší pozornosti odborné veřejnosti. Také se klade otázka, zda je poměrně radikální „dotvářeni““ rodinného práva věcí soudů. ${ }^{11}$

Společnost, zákonodárci, ústavní soudy a v neposlední řadě i Evropský soud pro lidská práva mnohdy stojí před velmi složitými úkoly. Dochází k pronikání cizorodých institutů do ustálených konceptů. Na první pohled se může jevit velmi obtížné uvažovat o evropských standardech. Nicméně, někteří familiaristé hovoří o postupném faktickém sbližování rodinných práv v Evropě a o jejich harmonizaci ve světle obecně uznávaných hodnot evropské civilizace. ${ }^{12}$ Nejde však jen o obecné principy. Ve vazbě na různé průniky, vzájemné ovlivňování právních řádů v důsledku volného pohybu osob, které uzavírají manželství, mají děti, rozvádějí se, soudí se o výživné apod., na které je reagováno především v rovině procesního práva a mezinárodního práva procesního, se navzájem přibližují i rodinná práva v evropských zemích.

České rodinné právo nestojí mimo výše uvedené evropské tendence. ${ }^{13} \mathrm{~S}$ ohledem na historický vývoj je možné dokonce říci, že v některých aspektech „udávalo“ směr. V současné době, kdy si připomínáme sté výročí založení Masarykovy univerzity, je namístě

6 Viz II. ÚS 3122/16 ze dne 16. května 2017.

7 Viz I. ÚS 3226/16 ze dne 29. června 2017.

8 Viz zákon č. 89/2012 Sb., občanský zákoník, v původním znění.

9 K tomu srov. ELIÁŠ, K. a M.. ZUKLÍNOVÁ. Principy a východiska nového kodexu soukromého práva. Praha: Linde, 2001, a řadu časopiseckých studií z pera hlavních zpracovatelů.

10 Srov. věcný záměr Ministerstva spravedlnosti č. j. 2623/00-L ze dne 29. ledna 2001, ze kterého vyplývá snaha o vytvoření evropského kontinentálního civilistického pojetí rodinného práva na straně jedné a na zachování jistého statusu quo na straně druhé.

$11 \mathrm{~K}$ tomu podrobně viz KOZUBÍK, J. a J. WINTR. Ústavní soudy a práva gayů a leseb - veřejné mínění jako determinant rozhodnutí soudů? Jurisprudence, 2016, č. 5, s. 34 a násl.

12 Srov. MEULDERS-KLEIN, M.-T. Towards a European Civil Code on Family Law? Ends and Means. In: BOELE-WOELKI, K. (ed.). Perspektives for the Unification and Harmonisation of Family Law in Europe. Antwerp - Oxford - New York: Intersentia, 2003, s. 111-112; ANTOKOLSKAIA, M. The Harmonisation of Family law: Old and new Dilemmas. European Review of Private Law, 2003, s. 28-49; díle ANTOKOLSKAIA, M. Harmonisation of Family Law in Europe: A Historical Perspective. A Tale of two millennia. Antwerpen - Oxford: Intersentia, 2006; ANTOKOLSKAIA, M. (ed.). Convergence and Divergence of Family Law in Europe. Antwerpen - Oxford: Intersentia, 2007.

13 Viz KRÁLÍČKOVÁ, Z. „Evropeizace“ rodinného práva. In: HURDÍK, J., M. SELUCKÁ, P. KOUKAL a kol. Evropské sonkromé práva v čase a prostoru. I. dil: Cást teoretická, metodologická a systémová. Brno: Masarykova univerzita, 2017, s. 163 a násl. 
stručně zmínit legislativní vývoj českého rodinného práva po roce 1918, resp. v roce 1919, a poukázat na hodnoty, na které lze i dnes navázat. Není bez zajímavosti, že i v době, kdy bylo více méně všeobecně uznáváno, že je třeba učinit radikálnější reformu manželského práva, zaznívaly zcela konzervativní názory a byla vedena protireformní kampaň. ${ }^{14}$

\section{Tzv. manželská novela v širších souvislostech}

Odborné veřejnosti je známo, že po vzniku Československa v roce 1918 bylo rodinné právo na území dnešní České republiky ovládáno Obecným qákoníkem občanskeým z roku $1811^{15}$ (dále zejm. o.z. o.) a na Slovensku právem uherským. ${ }^{16}$ Poměrně komplikované právní úpravy manželského práva, zejména pak uzavření a zrušení manželství za života manželů, byly v tehdejším Československu v průběhu let terčem kritiky laiků i odborné veřejnosti. Vznikly mnohé komise, které se měly zaobírat nejen reformami, ale zejména unifikací rodinných práv. Zmíněný dualismus se snažila překonat zvláštní meziministerská komise, z jejîhož pera vzešel významný počin, který vnesl do manželského práva převratné změny. Již v době záhy po první světové válce bylo mnohým z odborné i laické veřejnosti jasné, že hodnoty, na kterých bylo vybudováno rodinné právo zakotvené do obecného občanského zákoníku stojícího na konfesním přístupu, neobstojí tváří v tvář nové Ústavě Československé republiky, ${ }^{17}$ zejména jde-li o rovnost muže a ženy, zrovnoprávnění dětí narozených mimo manželství s dětmi manželskými a o svobodu člověka vůbec.

Výše zmíněným zákonem byla tzv. manželská novela, resp. manželský zákon či rozlukový zákon, ${ }^{18}$ tj. zákon, kterým se mění ustanovení občanského práva o obřadnostech smlouvy manželské, o rozluce a o překážkách manželství (dále zejména novela či manž. nov.). Tento zákon částečně sjednotil dílčí, ale velmi významnou oblast manželského práva na území nově vzniklého Československa, nejen jde-li o dualismus rakouského a uherského práva, ale zejména a především co se týká náboženských vlivů. V Obecném

14 Jde-li o jednotlivosti, kampaň hlásala kupř. obavy ze zavedení mnohoženství a zapuzování starých žen manžely ve prospěch mladších a cílila na zachování nerozlučitelnosti manželství. Blíže viz KLABOUCH, J. Manželstvi a rodina v minulosti. Praha: Orbis, 1962, s. 165.

15 Zákon č. 946/1811 Sb., obecný zákoník občanský převzatý do našeho právního řádu tzv. recepční normou, zákonem č. 11/1918 Sb., o zrrízení samostatného státu československého.

16 Pro rozvod a rozluku zůstalo v platnosti uherské právo. K tomu viz FAJNOR, V. a A. ZÁTURECKÝ. Nástin súkromnébo práva platnébo na Slovensku a Podkarpatskej Rusi. 3. vyd. Heuréka, 1998.

17 Srov. zákon č. 121/1920 Sb., kterým se uvozuje ústavní listina Československé republiky, zejm. \106 Rovnost a $\int 107$ Svoboda osobní a majetková.

18 Srov. zákon č. 320/1919 Sb. Novela převzala také dosavadní právní úpravu rozluky pro nekatolíky. K tomu viz SEDLÁČEK, J. In: ROUČEK, F., J. SEDLÁČEK a kol. Komentár ke československému obecnému zákoníku občanskému a občanské právo platné na Slovensku a v Podkarpatské Rusi. Díl prvni (』 1-284). Praha: Právnické knihkupectví a nakladatelství V. Linhart, 1935, s. 630. Dodejme, že citovaný zákon byl měněn 3 následnými novelami. Následně byl přijat zákon ze dne 15. 10. 1925, č. 219 Sb. z. a n., kterým se promíjí překážka platnosti sňatků, při nichž vyhlášky neb oddavky vykonali duchovní církve československé nebo řecko-východní. 
zákoníku občanském byly totiž zakotveny „Výjimky pro židovstvo“, ze kterých se podávalo, že o „,̌̌idovstvu platí se žretelem ke jeho náboženskému pomèru... odchylky od obecného manželskébo práva... "týkající se překážek manželství, ohlášek, rozvodu i rozluky (viz \123 a násl. o. z. o.). Také lze říci, že do manželského práva vnesl tento zákon určitá zjednodušení, která z dnešního pohledu hodnotíme jako pozitivní. Tzv. manželská novela však nezakotvila žádné změny do manželského majetkového práva.

\section{Tzv. manželská novela $\mathrm{v}$ jednotlivostech}

\subsection{O uzavírání manželství}

Pokud jde o uzavírání manželství, lze říci, že tzv. manželská novela navázala na tradiční koncept smlouvy manželské tak, jak ji upravoval obecný zákoník občanský (viz \44 a násl. o. z. o.). Je zajímavé, že byt’ název zákona používal termín „smlouva manželskáa“, v samotném textu zákona je užita terminologie odlišná. Již z úvodních ustanovení se podává, že „Kplatnosti manželstui se vyhledávaji vyhlášky a slavnostnè učinèné privoleni k manželství, a to bud” občanské, bud' církevni“" (viz \1 manž. nov.). ${ }^{19}$ Příslušné „privvoleni" bylo možné učinit jak před přednostou politického úřadu okresního či obecního nebo jeho zástupcem, v prrítomnosti dvou svědků a prrísežného zapisovatele (\8 manž. nov.). Zákon umožňoval i delegaci z místně príslušného úřadu na jiný ( 8 in fine manž. nov.) a také uzavření manželství prostřednictvím zástupce ( $\int 9$ manž. nov.). V případě církevního sňatku bylo stanoveno, že „oddavky “se konají před příslušným duchovním správcem a při smíšeném manželství před jedním anebo „u obou podle viile snoubencư“ (viz \ 12 manž. nov.); podle obecné úpravy pro obě formy sňatku museli být i sňatečnému projevu vůle u církevního sňatku př́tomni dva svědkové a zapisovatel ( $\int 8$ manž. nov.).

Jde-li o formu uzavření manželství dle předmětné novely, z výše uvedeného se podává vysoká míra tolerance a úcty k nejintimnějším potřebám snoubenců. Nová právní úprava uzavírání manželství zakotvovala skutečnou volbu mezi občanským (byt' na prvním místě uvedeným) a církevním sňatkem. Po dlouhá léta bylo totiž uzavírání manželství podle obecného zákoníku občanského umožněno pro přislušníky všech náboženských vyznání pouze církevní formou (viz \69 a \126 o. z. o.). ${ }^{20}$ Poté, co byl mezi Rakouskem a „stolicí papežskou“ sjednán konkordát, byla pro katolíky zrušena ustanovení obecného občanského zákoníku o manželství a soudnictví v manželských věcech katolíků bylo přeneseno na soudy duchovní. ${ }^{21}$ Jde-li o tzv. jinověrce a bezvěrce, vývoj právní úpravy byl v 19. a na počátku 20. století poměrně dramatický. Zvláštní zákon následně upravoval

19 Tzv. manželská novela směšovala vznik manželství s jeho platností. Bylo také zakotveno, že „Bude-li šetreno tohoto prèdpisu, jest k manželství hledèt tak, jako by bylo platně uzavreno hned od pưvodu" (viz S 7 in fine manž. nov.).

20 Obecný občanský zákoník byl v tomto směru měněn, zejména zákonem upravujícím sňatky mezi příslušníky rưzných vyznání křest’anských. Viz zákon ze dne 31. prosince 1869, č. 4 ř. z.

21 Viz císařský patent $z$ 8. ř́ina 1856, č. 185 ř. z. 
manželské právo pro osoby nenáležející k žádné konfesi22 a další zákon pak manželské právo mohamedánů ritu hanifovského. ${ }^{23}$ Je zajímavé, že už za účinnosti obecného zákoníku občanského byl přijat zákon, který zavedl pro všechna státem uznaná vyznání náboženská bez rozdílu také civilní formu uzavření jako formu „podpornou“, pokud duchovní oddávající odepřel celebrovat sňatek z důvodu, který obecný zákoník občanský neupravoval a zejména zrušil působnost církevního práva manželského a církevního soudnictví pro katolíky, kteří byli následně „podrobeni“ opět ustanovením obecného zákoníku občanského. ${ }^{24}$ Následně byl přijat zákon, který zavedl obligatorní občanský sňatek pro osoby nenáležející $\mathrm{k}$ žádnému vyznání. ${ }^{25}$ Fakultativní občanský sňatek byl ustanoven pro zvláštní prrípady, kupř. když byl jeden ze snoubenců žid a druhý př́slušníkem vyznání státem neuznaného. ${ }^{26}$

Jak bylo výše ukázáno, právní úprava uzavírání manželství a manželského práva vůbec byla silně ovlivňována „bojem“ mezi státem a církví. Proto nepřekvapí, že původní návrh tzv. manželské novely z pera příslušné komise obsahoval pouze obligatorní civilní sňatek. ${ }^{27}$ Tato př́lišná „,tvrdost“ zákona byla v průběhu legislativních prací na tzv. manželské novele odstraněna a snoubencům byl ponechán prostor pro volbu formy uzavření manželství ve vazbě na princip náboženské svobody, deklarovaný v Ústavě Československé republiky. ${ }^{28}$ Navíc bylo v zákoně stanoveno, že i manželům již oddaným občanským sňatkem ,je dáno na viili, chti-li se podrobit také obradưm církevním" (viz \12 manž. nov.). Z povahy věci nepřicházel v úvahu opačný postup, tj. po obřadu církevním podstoupení civilního oddání, nebot' manželství vzniklo již samotným přivolením k manželství tak, jak bylo uvedeno výše.

\subsection{O vyhláškách}

Vlastnímu uzavření manželství, at' už formou občanskou či církevní, muselo předcházet tzv. předoddavkové řízení obdobné řízení podle současné právní úpravy jen s tím rozdílem, že nebylo obligatorně civilní tak, jak dnes (viz zejm. \ 666 odst. 2 o. z.). Účelem vyhlášek a všeho dalšího, co s nimi bylo spojeno, bylo zkoumání sňatečného věku a překážek či zápovědí manželství tak, aby ve statusových věcech rodinných byl ctěn zákon,

\footnotetext{
22 Viz zákon ze dne 9. dubna 1870, č. 51 ř. z.

23 Zákon ze dne 15. července 1912, č. 159 ř. z.

24 Srov. zákon ze dne 25. května 1868, č. 47 ř. z.

25 Viz zákon ze dne 9. dubna 1870, č. 51 ř. z.

26 Viz KRČMÁŘ, J. Právo rodinné. Praha: Všehrd, 1923, s. 14.

27 K tomu např. GERLICH, K. Rozvod, rozluka, alimenty. Praha: Právnické knihkupectví a nakladatelství Linhart, 1934, s. 17.

28 Viz pozn. č. 17 výše, \121 až 125, garantující svobodu svědomí a vyznání, náboženství či víry.
} 
veřejný pořádek a v neposlední řadě i dobrá víra snoubenců ve vznik platného manželství. ${ }^{29}$ Bylo stanoveno, že vyhlášky sledovaly „oznámení budoucího manželstvi“ a obsahovaly „jméno a prójmeni obou snoubencui, jejich rodisté, stav a bydlište" a také „prïpomenutí, aby každý, kdo védèl o nèjaké préeáą̌ce manželstuí, je oẓnámil" (viz \ 2 manž. nov.).

Zákonná úprava okruhu překážek či zápovědí manželství byla v obecném zákoníku občanském v původním znění poplatná kanonickému právu. ${ }^{30}$ Teorie rozlišovala překážky na absolutní a relativní. ${ }^{31} \mathrm{~V}$ průběhu let byla také vytvořena překážka tzv. katolicismu. ${ }^{32}$ Vedle soukromoprávních překážek v užším smyslu znal tehdejší právní řád také překážky veřejnoprávní, jejich účelem bylo zamezit „manželství príčici se nékterým zájmuim neb aspoñ chtit dáti určitým orgánuim možnost prozkoumati, zda-li zamýšlené manželství není v odporu se zájmy, keteré zaslubuji ochrany “33 Šlo o překážky stanovené pro osoby, které byly povinny vojenskou službou (nesměly do manželství vstupovat bud' vůbec, anebo bez svolení příslušných úřadů) a pro prŕíslušníky četnictva (mohli se ženit jen tehdy, když měli tzv. definitivu a dovršili čtyřletou službu u četnictva anebo 30. rok věku). ${ }^{34}$ Zvláštní překážky byly vytvořeny pro židy. ${ }^{35}$ A navíc, postupně se začaly vytvářet př́kážky pro vstup do manželství také vesnické a městské chudině, která nebyla s to garantovat svoji schopnost živit př́ípadné potomstvo. ${ }^{36}$ Nárůst politického napětí vedl až k zavedení tzv. politických konsensů $\mathrm{k}$ sňatku, které byly na nátlak liberálů záhy zrušeny. ${ }^{37}$

Lze říci, že přijetí tzv. manželské novely muselo znamenat pro každého, kdo chtěl uzavřít manželství, významný mezník a velkou úlevu. Především bylo důležité, že ve vazbě na zavedení volby občanské formy uzavření manželství bylo na prvním místě zakotveno, že občanské vyhlášky činí politický úřad okresní či obecní a na Slovensku matrikář (viz \3 manž. nov.). Zákon dále specifikoval místní př́íslušnost, možnost delegace, tzv. deliberační lhůtu, po které mohlo dojít k přivolení k manželství snoubenci, resp. k jejich prohlášení o vstupu do manželství, možnost zkrácení lhůty kupř. z důvodu

29 K některým překážkám se muselo přihlížet ex offo, kupř. pokud šlo „o únos, trvajíci manželství, pokrevni príbużenství, úklady o život prekéážejicího manžela... ". Blíže viz SVOBODA, E. Rodinné právo. Praha: Vesmír, 1921, s. 16 a násl.

30 Ke kritice zápovědí manželství, zejména „nepřijatelných pro diskriminační povahu“, viz HADERKA, J. Uzavíráni manželstvi z blediska právníbo. Praha: Academia, 1977, s. 86 a násl.

31 K tomu blíže KRČMÁř, J. Právo rodinné. Praha: Všehrd, 1923, s. 6.

32 Šlo o roky 1814 a $1835 . \mathrm{K}$ tomu v detailech viz SVOBODA, E. Rodinné právo československé. Praha: Kompas, 1946, s. 12 a násl.

33 Blîže viz KRČMÁŘ, J. Právo rodinné. Praha: Všehrd, 1927, s. 26.

34 Ibid., s. 26 a 27.

35 Bliže viz KLABOUCH, J. Manželství a rodina v minulosti. Praha: Orbis, 1962, s. 124.

36 Kupř. v roce 1815 byl vydán předpis omezující vstup do manželství námezdně pracujících ve Vídni. KLABOUCH, J. Manžęlstuí a rodina v minulosti. Praha: Orbis, 1962, s. 126.

37 Jde-li o důvody zavedení a zrušení politických konsensů „zbídačeným proletáruom “, viz KLABOUCH, J. Manželstvi a rodina v minulosti. Praha: Orbis, 1962, s. 137. 
„blizké nebezpečenství smrti“ či dokonce její prominutí (viz \4 a 7 manž. nov.) a povinnost vyhlášky za určitých okolností opakovat (\$ 6 manž. nov.).

Pokud jde o sňatek uzavíraný církevní formou, vyhlášky se konaly u příslušného duchovního správce. Jestliže byli snoubenci smíšeného náboženství, vyhlášky se měly dle zákona konat u obou duchovních správců a to před věřícími při bohoslužbě.

Jde-li o překážky manželství, tzv. manželská novela především výslovně limitovala překážku švagrovství (viz \25 odst. 3 manž. nov.) a zcela zrušila překážku vyššího svěcení a řeholních slibů (viz původní $\int 63$ o. z. o.), překážku tzv. katolicismu (viz výše) a cizoložství a odstranila zvláštní vymezení překážek pro židy. Další soukromoprávní překážky a zápovědi byly upraveny i nadále v obecném zákoníku občanském (\ 48 a násl. o. z. o.).

\subsection{O rozvodu, resp. rozluce}

Jak již bylo uvedeno výše, právní úprava manželství a jeho rozluky byla v Obecném qákoníku občanském poměrně komplikovaná, což bylo dáno dobou jeho vzniku a mnohými vlivy. Kodex rozlišoval mezi rozvodem od stolu a lože (dohodnutým či bez dohody), v důsledku kterého mohlo být manželům pouze povoleno oddělené bydlení ( $\int 103$ a násl. o. z. o.), a roz̧lukou manželství, která znamenala zrušení manželství za života manželů, nicméně byla začleněna právě do části nazvané „Výjimky pro židovstvo“ (viz \133 a násl. o. z. o.). Pro manžele katolického vyznání tak bylo manželství za života v podstatě nerozlučitelné. Platila zásada ,dokud nás smrt nerozděli" (\$ 111 s násl. o. z. o.). ${ }^{38} \mathrm{Jde}$-li o tzv. jinověrce a bezvěrce, byla pro ně postupně vytvořena zvláštními zákony citovanými výše specifická pravidla. $^{39}$

Jde-li o zrušení manželství za života manželů, tzv. manželská novela zakotvila pro rozluku zásadně jednotný režim bez ohledu na konfesi manželů v podobě kazuisticky vyjmenovaných di̊vodů, kupr. cizoložství, opuštèni či vedeni zhýralébo života anebo pro trvale nebo periodicky probíhajici duševni chorobu, která trvá tři léta atd. (viz \13 manž. nov.).

Právě duševní porucha jako důvod pro zrušení manželství byla novinkou, kterou novela zavedla. V odborné literatuře bylo v této věci uvedeno, že v občanském zákoníku tento důvod chyběl, což bylo považováno za ,mežeru velmi citelnou, protože nutila k spolužiti s manželem slabomyslným nebo epileptikem nebo chorobomyslným, at' už se volně pobyboval nebo trávil konec života v ústavu chorobomyslných bez nadèje na záchranu. " ${ }^{40}$ Dále bylo vysvětlováno, že „Ve vètšinè qákonu novodobých jest pamatováno na toto strašlivé zlo, a byla dána možnost záchrany manželu, nucenému ke intimnimu životu s člověkeem neprǐčetným, z̦traceným a nebezpečným."

\footnotetext{
38 K tomu blíže KRÁLÍČKOVÁ, Z. a L. ZATLOUKALOVÁ. Dokud nás smrt nerozdělí: úvahy nad právem na rozvod. Právní roz̧hledy, 2019, č. 17, s. 573-580.

39 Viz pozn. č. 22, 23 a 26 výše.

40 Tak GERLICH, K. Rozvod, roz̨luka, alimenty. Praha: Právnické knihkupectví a nakladatelství Linhart, 1934, s. 159.
} 
Také bylo poukazováno na fakt, že slova „chorobomyslnost“ je třeba užívat velmi opatrně a že osnova zákona záměrně nepoužila pojmu ,nevyléčitelnosti“s tím, že je třeba sáhnout k jinému kritériu, tj. „... pokud možno spravedlivě na manželu žádati spoluřití s chorým na duchu a pokud eventuálni zplozeni dètí jest považovati za žádouci z. hlediska żdravého potomstva ".41

Jako jeden z důvodů pro možnost žalovat o rozluku manželství byl dále uveden bluboký rozurat manželský. Ten byl pojat dle švýcarského zákona ${ }^{42}$ jako stav, kdy na manželích nebylo možné požadovati, aby setrvali v manželském společenství [\$ 13 písm. h) manž. nov.].

Z poměrně bohaté judikatury k předmětnému ustanovení se kupř. podávalo, že „Nejde o bluboký rozurat manželský, lze-li vz̧bledem k. mladému věku a krátkému spolužití manželu míti za to, ž jade spiše o nedostatek životni zkušenosti a o nedostatečné vájemné porozumèni pro práva a povinnosti manželské a pro manželské soužiti“"43 a že „Manželce nelze pričitati za vinu na rozuratu, nenásledovala-li manžela do <společné domácnosti>, již, mély tvorit dva hotelové pokoje bez kuchyné"

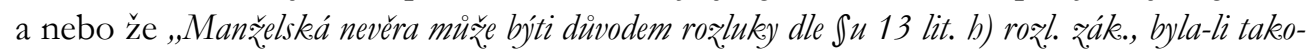
vébo rázu, že nelže spravedlivě po klamaném manželovi požadovati, aby setrval v manželském spojeni" “45 a že „I odpušténé cizoložstvi lze hodnotiti jako spoluprícínu roẓvatu“"46

$\mathrm{K}$ výše uvedenému je třeba dodat, že manželství nemoblo být rozloučeno ke žalobě manžela prevážné vinného rozvratem [S 13 písm. h) in fine manž. nov.]. Nicméně, dle Jaromíra Sedláčka zákon nepředpokládal u žalovaného manžela vinu na rozvratu, zároveň ji však nevylučoval u manžela žalujícího, který pro úspěšnost žaloby o rozvod neměl být vinen rozvratem převážně. ${ }^{47}$ $\mathrm{K}$ tomu dobová judikatura dále uváděla, že „Rozvrat manželství nemusí být zpiosoben vinou manželu (jednoho z nich), nýbrž i osobou třetí, nebo vỉbec i okolim (prostredim) ba dokonce i bez vši viny nèjaké osoby. Prí takové objektivni pricinè nutno zkoumati (prevážnou) vinu jednoho z. manželü. "48

Pokud se však domáhali rozluky pro rozvrat oba manželé, nebylo třeba podle soudní praxe zkoumati, „kdo z nich je prevážně rozuratem vinen “49

Posledním důvodem pro rozluku uvedeným v zákoně byl neprekonatelný odpor, pro který bylo možné manželství rozloučit jen tehdy, pokud se kžalobě - třeba i dodatečně - připojil

41 GERLICH, K. Rozvod, rozluka, alimenty. Praha: Právnické knihkupectví a nakladatelství Linhart, 1934, s. 159 až 160.

42 Cit. dle díla GERLICH, K. Rozvod, rozluka, alimenty. Praha: Právnické knihkupectví a nakladatelství Linhart, 1934, s. 161.

43 Viz Rozh. ze dne 16. 5. 1931, Rv II 485, čís. 10.793.

44 V detailech Rozh. ze dne 23. 8. 1928, Rv II 693/27, čís. 8243.

45 Rozh. ze dne 7. 3. 1923, Rv I 1037/22, čís. 2365.

46 Tak Rozh. ze dne 3. 7. 1923, RV II 92/23, č́s. 2796.

47 Srov. SEDLÁČEK, J. In: ROUČEK, F., J. SEDLÁČEK a kol. Komentár k československému obecnému zákoniku občanskému a občanské právo platné na Slovensku a v Podkarpatské Rusi. Dil proní (J 1-284). Praha: Právnické knihkupectví a nakladatelství V. Linhart, 1935, s. 639.

48 Viz Rozh. ze dne 19. 5. 1925, Rv I 684/25, č́́s. 5050.

49 Tak Rozh. ze dne 7. 12. 1920, Rv I 670/20, č́s. 800. 
i druhý manžel; v tomto případě bylo také možné žalobě na rozluku nevyhovět a „napred užnati na rozuod od stolu a lože" [S 13 písm. i) manž. nov.].

Z judikatury se k tomu podávalo, že „Nepřekonatelný odpor nemusí býti vzájemným... stači, je-li jen na straně jednoho manžela proti druhému, ale oba manželé musi býti za jedno, že žádají, aby rozluka byla povolena... projev soublasu s rozlukou jest neodvolatelný... manžel, svolivši z. bezvadnébo rozhodnuti ville k žádosti o rozluku, neni oprávnèn činiti napotom svịj soublas závislým na podmince týkajici se úpravy pomèru majetkových... "50

Také bylo judikováno, že „Projevila-li manželke soublas s rozlukou manželství pro neprekonatelný odpor pod výminkou manželem neprijatou, že ji bude manžel poskytovat výživné, nelze soublas považovati za udèlený. "51

A konečně, v judikatuře bylo v návaznosti na (dnešní terminologii) dobré mravy konstatováno, že „Úmluva, již̃ jeden z. manželu za úplatu napred se zavazuje, že dá soublas k žalobè nebo žádosti drubébo man ̌̌ela o rozluku, je neplatná (I 879 obč. zák..). "52

$\mathrm{K}$ věci dále dodejme, že. soud měl dle dalšího ustanovení novely také povinnost převzít výrok o vině do usnesení o rozluku manželství z rozsudku vydaného ve sporu o rozvod manželství (\ 17 manž. nov.). Zákon též stanovil poměrně detailně zvláštní pravidla pro promlčení práva žalobního (viz $\int 14$ manž. nov.) a další procesní věci, kupř̀ pro uplatnění vyšetřování dle zásad rrízení nesporného a domněnku $\mathrm{v}$ př́ípadě, kdy se manžel k řízení nedostaví (viz $\int 16$ manž. nov.) a také možnost soudu nařídit ústní neveřejné (sic!) jednání, a to i před senátem (viz \21 manž. nov.). ${ }^{53}$

\section{3 Úvahy nad evropskými hodnotami v manželském právu v historických souvislostech}

Pokud jde o uzavíránímanželství, jeho prekážky a rozvod manželství, lze napříč evropskými zeměmi - i ve vazbě na jejich politické, společenské, náboženské, hodnotové a hospodářské proměny - pozorovat podobné tendence vývoje právní úpravy.

Možná překvapivě lze na základě letmého pohledu do evropských právních úprav dospět k závěru, že mnohé zákoníky či samostatné kodexy rodinného práva umožňují lidem zvolit si pro uzavreni manželstvi obě tradični formy, civilní i církevní, byt' spíše jen před tzv. tradičními církvemi. To souvisí především s pádem železné opony a opuštěním sovětské doktríny rodinného práva, která církevní sňatek zcela odsoudila jako buržoazní přežitek. Nejen v zemích bývalého Sovětského svazu, ale i v Česku, na Slovensku, $\mathrm{v}$ Polsku a v jiných posttotalitních zemích našel církevní sňatek opět své místo

\footnotetext{
50 Viz Rozh. ze dne 21. 1. 1928, R I 4/28, čís. 7710.

51 Rozh. ze dne 18. 7. 1928, R II 302/23, čís. 2834.

52 Tak Rozh. ze dne 26. 4. 1921, R II 18/21, čís. 1033.

$53 \mathrm{~V}$ podrobnostech i ve vazbě na procesní normy viz GERLICH, K. Soudní rízeni ve věcech manželských. Praha: Orbis, 1939.
} 
v zákonících, ale i v běžném životě. Samožrejmě, v zemích, kde měl vždy své místo, zůstal i po významných změnách v rodinném právu ponechán, kupř. v Itálii, Velké Británii či severských zemích. Je tak možné říci, že je dobře, že i tvưrci tzv. manželské novely, jejíž přijetí si v těchto dnech připomínáme, obě formy uzavření manželství v našem právním prostředí zachovali a člověku tak ponechali právo volby dle jeho nejniternějších potřeb a přání. Obdobně i nový občanský zákoník.

Naopak, jde-li o okrub zákonných prekéą̌ek manželství, postupně se v mnoha zemích zredukoval pouze na ty, které souvisí s tradicemi křest’ansko-židovské kultury (kupř. jiné manželstvî) či veřejným pořádkem a dobrými mravy, resp. rozumným uspořádáním věcí vůbec (blízké příbuzenství). Česká právní úprava manželských překážek zakotvených do současného občanského zákoníku je minimalistická a plně dostačující (viz \672 a násl. o. z.). Každý člověk má právo žít podle svého. Pokud se rozhodne vstoupit do manželství, nesmí mu stát v cestě bariéry, které jsou historicky podmíněné a které nemají v dnešní době rozumné odůvodnění. S tím souvisí i problematika manželství zdánlivého, tj. takového, které nevznikne, pokud nebyly splněny takové náležitosti, na jejichž splnění je třeba bezvýhradně trvat, resp. když to zákon výslovně stanoví (\$ 677 a násl. o. z.). Od tohoto „nemanželství“ je třeba odlišovat manželství, které sice i přes překročení zákonných překážek vznikne, ale které by mělo být soudem prohlášeno za neplatné, at' už k návrhu či ex offo (viz \680 a násl. o.z.). Současná právní úprava umožňuje soudu intervenovat do nejintimnějších věcí člověka pouze omezeně, jde-li právě o narušení veřejného pořádku, vazbu na trestné činy (kupřr. bigamie) apod. Opět je možné v této souvislosti poznamenat, že tzv. manželská novela naznačila, jde-li o překážky manželství, správný směr. Jinou věcí zůstává věc tzv. genderově neutrálního manželství, které do mnoha evropských právních řádů postupně proniká a velmi úzce souvisí také s problematikou překážek manželství (stejné pohlavî). Jmenovitě se jedná nejen o Nizozemí a Francii, ale i o Rakousko, do jehož obecného zákoníku občanského, který byl pramenem rodinného práva po dlouhá léta i u nás, bylo poměrně nedávno významně zasaženo tamním Ústavním soudem. ${ }^{54}$

Pokud jde o rožvod manželství, ještě v polovině 20. století byl považován za stigma, nebot' většinová společnost kladla důraz na mravnost a zachování rodiny. ${ }^{55}$ Postupně se však postoje a názory podstatně uvolňovaly. ${ }^{56} \mathrm{Od}$ církevního konceptu téměř nerozlučitel-

$54 \mathrm{~K}$ tomu blíže DEIXLER-HÜBNER, A. Öffnung der Ehe für gleichgeschlechtliche Paare in Österreich ab 1. 1. 2019. In: Dny práva 2018 - Days of Law 2018 [online]. Brno: Masarykova univerzita, 2019. ISBN 978-80-210-9304-1.

55 K tomu viz HADERKA, J. Rozvod v soućasném svétě. Díl I a II. Praha: Ministerstvo spravedlnosti, $1987,1989$.

$56 \mathrm{~K}$ vývoji rozvodového práva a komparativním závěrům viz zejména VERSCHRAEGEN, B. Divorce. The International Encyclopedia of Comparative Law, Tübingen, 2004, roč. IV, kap. 5. V současné době umožňují rozvod jako zrušení manželství za života manželů všechny evropské státy, včetně Malty, která tak učinila v roce 2011. Viz zákon č. XIV z 29. 7. 2011, který novelizoval Občanský zákoník Malty. Dostupné z: http://www.justiceservices.gov.mt/DownloadDocument.aspx?app=lp \& itemid=22432 \& l=1 [cit. 5. 5. 2019]. 
ného manželství, resp. rozvodu založeného na vině, kdy nebylo možné manželství rozvést na návrh rozvratem vinného manžela, směřoval vývoj k principu rozvodu založeného na tzv. kvalifikovaném rozvratu až po tzv. smluvený neboli konsensuální rozvod a posléze byl $\mathrm{v}$ mnoha právních řádech ukotven administrativní rozvod. ${ }^{57}$ Výše citovaná tzv. manželská novela rozvodová pravidla významně zjednodušila, byt' se to tak z dnešního pohledu nemusí jevit. I současná česká právní úprava rozvodu je založena na tzv. kvalifikovaném rozvratu. Je otázkou, zda odpovídá evropskému vývoji a potřebám současné české společnosti. Jde-li o tzv. rozvod se zjišt’ováním příčin rozvratu v obecné rovině (\ 755 a $\int 756$ o. z.), je třeba říci, že na tzv. kvalifikovaný rozvrat poměrů mezi manžely lze usuzovat více z faktické odluky manželů než z podání manželů, resp. jejich výslechu, ve vazbě na vylíčení průběhu manželství a příčin rozvratu. ${ }^{58}$ Také je potreba konstatovat, že pokud oba manželé usilují o rozvod manželství a jsou dohodnuti na majetkovém vypořádání (dle \ 757 OZ), není zásadně nutné de lege ferenda trvat ani na osobní účasti u jednání u soudu, resp. je možné uvažovat o celkově liberálnější úpravě rozvodu vůbec ve světle Principu evropského rodinného práva, resp. o administrativním rozvodu po vzoru Model Family Code. Tato úvaha však nemá vést k lehkomyslnému př́stupu k manželství nebo k možnosti vytváření nátlaku na slabší stranu s účelem dosáhnout rozvodu rychleji či „snadněji““, naopak může být výrazem práva na spravedlivý proces a respektu k autonomii jednotlivců - manželů, kteří se rozhodli své manželství ukončit a budoucí poměry si smluvně upravit..$^{59}$

\section{Závěr}

Je možné konstatovat, že tzv. manželská novela přijatá před sto lety představuje výžnamný počin, který české rodinné právo ovlivnil na dlouhá léta.

Byl nastolen správný smèr svobodné volby civilní či církevni formy uzavreni manželství (od kterého se náš zákonodárce z politických a ideových důvodů po komunistickém převratu odchýlil, s tím, že k nápravě bylo přistoupeno až v roce 1992), došlo k omez̧eni prekážžek manželství a roz̧od maň̌elstuí, resp. pravidla pro zrušení manželství za života manželů

57 K tomu viz DUTTA, A., D. SCHWAB, D. HENRICH, P. GOTTWALD a M. LŐHNIG (eds.). Scheidung obne Gericht? Bielefeld: Gieseking, 2017.

58 Srov. PULKRÁBEK, Z. Přikazuje $\int 24$ odst. 1 ZOR soudu, aby zjistil prríčiny rozvratu manželství? Právní roz̧bledy, 2011, č. 2, s. 39 a násl. Autor poměrně rozsáhlé studie s bohatým poznámkovým aparátem poukazuje zejména na nevýhody zjišt'ování příčin rozvratu jak pro manžele samotné, resp. jejich duševní zdraví a pohodu a schopnost porozvodové komunikace, zejména mají-li nezletilé děti. Dále si klade otázku, zda je vůbec v lidských silách tyto př́činy zjistit. Konstatování, že na rozvrat lze usuzovat spíše $\mathrm{z}$ „projevui neboli následkư rozuratu" než z příčin, vyvěrá z hluboké lidské i profesní zkušenosti.

59 Srov. SCHWENZER, I. Model Family Code. From a Global Perspective. Antwerpen-Oxford: Intersentia, 2006, s. 29. Dikce připouští (Article 1.14) administrativní rozvod manželství v případě, že manželé nemají společné nezletilé děti, délka manželství nepřekročí deset let a manželé se na samotném rozvodu a jeho důsledcích dohodli a souhlasí s postupem administrativním. Zmíněné podmínky mají zajistit dostatečnou ochranu společných nezletilých dětí manželů i ochranu slabší strany. 
se významně zjjednodušila. Rozluka podle citované novely byla vnímána jako legitimní řešení manželské krize bez zbytečného prodlužování nefunkčních, tzv. mrtvých manželství, čemuž významně napomáhalo i novelizované procesní právo.

V kontextu své doby - psal se rok 1919 - a následného vývoje v evropských zemích, naše území nevyjímaje, je možné konstatovat, že tzv. manželská novela, jejíž sté výročí si letos připomínáme, byla kvalitním legislativním dílem, adekvátně vycházejícím vstříc potřebám společnosti, svobodných lidí a jejich právu na rodinný život dle své vlastní volby. ${ }^{60}$

Klade se otázka, jaké jsou potřeby současné české společnosti. Je věcí (nejen) společenských věd, aby tak významné téma, jako je manželství, jeho podoba a možnost zrušení za života manželství podrobily důkladnému zkoumání ve vazbě na evropský vývoj. Také by měla být zahájena celospolečenská diskuse na tato témata, zejména jde-li o aktuální legislativní návrhy, které jsou součástí „prorodinného balíčku“ (sic!) směřujícího k tzv. rozvodu u notáře. ${ }^{61}$

60 Ostatně i historická literatura ji hodnotila jako „vyhovnjicí modernímu názoru prámímu“. Blíže viz SVOBODA, E. Rodinné právo československé. Praha: Kompas, 1946, s. 14.

61 Jde-li o názory publikované na stránkách Unie rodinných advokátů, jsou dostupné z: http://www.uracr. cz/nazory/rozvodunotare-anocine [cit. 22. 8. 2019]. 